Vol. 1, No. 2, 2020

Yuri Davidich, Yevhen Kush, Denys Ponkratov

O.M. Beketov National University of Urban Economy in Kharkiv

17, Marshal Bazhanov Str., Kharkiv, 61002, Ukraine

(C) Yu. Davidich, Ye. Kush, D. Ponkratov, 2020

https://doi.org/10.23939/tt2020.02.023

\title{
CHANGE OF CAR DRIVER'S STRESS INDEX DURING DIFFERENT PERIODS OF THE DAY IN URBAN TRAFFIC CONDITIONS
}

\begin{abstract}
Summary. Nowadays, the transport industry plays an important role in human well-being and the functioning of any settlement. Transport systems are involved in almost all areas of production and services. Therefore, any failure in its operation can lead to significant material costs. One of the most important such systems is "driver - vehicle - road - environment". It should be noted, that the main link in it is "driver". The correctness and duration of decision-making in different road situations depend on the driver's functional state. This directly affects the level of traffic safety. Consequently, the tasks of modern transport research are the introduction of methods of the vehicle driver's conditions monitoring and the detection of his fatigue in its early stages. That's why the actuality of studying the human operator role in the transport process and the creation of modern means of driving assistance are increasing now.
\end{abstract}

Key words: stress index, psychophysiological indicators, functional state of the driver, reliability of the driver, the period of the day, urban traffic conditions.

\section{INTRODUCTION}

Intensive development of road transport in Ukraine annually requires an increase in the number of road vehicles drivers. This category of workers, due to the specifics of their work, is subject to several risks with negative forms of influence, actually material, moral, and psychological, which often lead to tragic results.

The process of road transport movement is highly complicated and unpredictable. This is due to many factors: road conditions, number of vehicles and their technical characteristics, psychological qualities and experience of the driver, etc. All these factors interaction can be combined in the system "driver vehicle - road - environment". It should be noted, that the driver is the main control link to this system. Peculiarities of the driver's profession are associated with the constant changes in traffic conditions, an accident's probability, and injuries of road users, that cause driver's psychological stress, disorders, and reduced reliability. This can lead to nervous imbalance and tension in the driver's body. This can usually manifest itself in the form of fatigue, lethargy, irritability, memory loss, decreased concentration, etc. To prevent such phenomena, each driver must have a clear idea of their emotional stress and mental fatigue limits in different road conditions. Therefore, his work must be regulated in time. The driver must know the period during which he can drive, how to travel a certain distance, and at what speed, with maintaining his efficiency and attention [1].

It should be noted, that the activity of a vehicle driver is associated with many basic psychophysiological qualities, which determine the suitability to drive a car (sensation, perception, psychomotor reaction, emotional reactions, work skills, operational thinking, etc.). Insufficient development of some of the driver`s psychophysiological features can be partially compensated by the development of others. It can be revealed in different conditions, when the avoidance of traffic accidents mainly depends on the speed of situation assessment, driving skills, reaction time, and resoluteness $[2,3]$. 
According to the above, the driver's operations effective side can be reflected in the form of the "functional state" concept. It means the ability of the subject to perform certain work depending on his condition. In this case, various forms of the organism`s activity can be characterized by the specific orientation of activity, motivation, and intensity of their display [4].

\section{RESEARCH STATEMENT}

This article aim is to identify the pattern of changes in the car driver's stress index (SI) during different periods of the day. To achieve the aforementioned aim, it is necessary to solve the following tasks:

- analyze the traffic conditions in which the driver was driving a car;

- conduct field research of indicators that are needed for determining the functional state of the driver;

- $\quad$ analyze the obtained data and set the value of the SI;

- identify the dynamics of changes in the drivers`SI during different periods of the day.

\section{RELIABILITY OF THE DRIVER, HIS FUNCTIONAL STATE, AND METHODS OF ITS RESEARCH}

The reliability of the driver is determined by his ability to drive unmistakably in all conditions during all working hours. Quantitative assessment of driver reliability is a challenge as nowadays modeling the driver's control properties is accompanied by several assumptions and caveats and is possible only in some cases. It is quantified by some parameters (operating time, failure time, total time, etc.) and different probability characteristics (probability of failure-free operation, probability of failure, etc.) [5].

The reliability of the driver's work in some papers is characterized by the frequency of errors that lead to failures, and the duration and accuracy of certain important operations. In this case, all failures of the driver often are divided into two categories: regular and accidental. The regular failures include all failures, the causes of which are known, or can be identified in the professional selection of drivers. Accidental failures - those which are related to the activities of the driver and have a probabilistic nature [6].

Depending on the type of operator activities as the main indicators of driver reliability, it is proposed to choose the ability: to make decisions quickly and correctly in situations of choice and stressful situations; to perceive and process information quickly $[5,6]$.

Scientists also note the concept of the driver's "physiological reliability". This reliability concerning temporary persistent failures due to the lack of time or the increase of fatigue and appearance of injury, stress, etc. This is because a continuous flow of information and physical activity during the movement influence the driver as well as a variety of information about the processes occurring in organism and environment. Perception of this information and its correct processing allow such sensations as visual, sound, and tactile $[4,6]$.

That is why, the ability of the driver to predict and react changes in the road situations, to take appropriate action in advance to prevent traffic accidents, etc, is important for road safety. This emphasizes that the driver is a key link in the system "driver - vehicle - road - environment".

One of the indicators that can reflect the reliability of the driver is his functional state. This indicator, together with the professional suitability of the driver are the main factors that determine the traffic safety and reliability of the human in the transport system. It should be noted that for each person there is an individual norm of a functional state and its indicators. For the investigation of the operator activities, it is possible to use psychological and physiological methods of analysis. The driver's functional state is a set of available characteristics of those operator's functions and qualities that directly or indirectly determine the performance of labor activity (labor functions). The state of driver's regulatory systems is the result of the dynamic interaction of the organism with the environment, which is characterized by the вшіздфн of the human's body qualities and properties. This condition depends on some factors [7-10]:

- motivation, 
- type of work,

- level of sensory load,

- the initial level of the nervous system activity,

- individual properties of the nervous system, etc.

It should be noted that people with a strong nervous system are less resistant to monotonous work. The level of nervous processes activity in their organisms is decreasing earlier. In this case, the formation of the person`s functional state significantly affects the reliability of his activity.

In medicine, the study of the human functional state is conducted to identify internal diseases and predict trends in their development. In ergonomics, the definition of the functional state is created based on information about the systemic changes that are developed in humans during the appropriate work. In this case, the condition of the organism is indicated as a kind of response of various body systems to external and internal influences. According to the level of applied physiology development, there are various methods of studying human's functional state, which can change under the influence of certain factors. Physiological parameters that are often analyzed are:

- blood pressure,

- respiration rate and depth,

- the volume of exhaled air per minute,

- oxygen consumption,

- skin reaction,

- changes in the biopotentials of the brain

- biochemical changes in blood,

- heart rate, and its variability, etc.

Respectively, the most common methods of functional state studying are tests and electrophysiological methods, to be exact, analysis of records $[10,11]$ :

- electrocardiogram (ECG);

- electroencephalogram (EEG);

- skin-galvanic reaction (SGR);

- electromyogram;

- electrooculogram;

The general characteristic of psychophysiological indicators, which are changing depending on a research method and a condition of an organism, is shown in Table $1[1,6,11,12]$.

Table 1

General characteristics of changes in psychophysiological parameters $[1,6,11,12]$

\begin{tabular}{|c|c|c|c|c|c|}
\hline \multirow{2}{*}{ Nomber } & \multirow{2}{*}{ Mental state } & \multicolumn{4}{|c|}{ Electrophysical parameters } \\
\hline & & EEG & ECG & Skin-galvanic reaction & Special tests \\
\hline 1 & 2 & 3 & 4 & 5 & 6 \\
\hline 1 & Calm attention & $\begin{array}{l}\text { Reduction of } \\
\text { alpha-rhythm } \\
\text { and the } \\
\text { appearance of } \\
\text { sigma-rhythm in } \\
\text { biopotentials }\end{array}$ & $\begin{array}{l}\text { Stabilization of the } \\
\text { pulse, a slight } \\
\text { change in the } \\
\text { systolic index }\end{array}$ & $\begin{array}{l}\text { Changes in potential } \\
\text { only with a positive } \\
\text { signal appearance }\end{array}$ & $\begin{array}{l}\text { Calm } \\
\text { expression, } \\
\text { good oral } \\
\text { arithmetic }\end{array}$ \\
\hline 2 & Stressful state & $\begin{array}{l}\text { Alpha-rhythm } \\
\text { and an increase } \\
\text { in delta-rhythm } \\
\text { caused by } \\
\text { potentials }\end{array}$ & $\begin{array}{l}\text { Increased heart rate, } \\
\text { increased systolic } \\
\text { rate }\end{array}$ & $\begin{array}{l}\text { The constant change } \\
\text { of potential, obvious } \\
\text { change with the } \\
\text { appearance of a } \\
\text { positive signal }\end{array}$ & $\begin{array}{l}\text { Calm } \\
\text { expression, } \\
\text { mistakes in } \\
\text { oral arithmetic }\end{array}$ \\
\hline
\end{tabular}


Table continuation 1

\begin{tabular}{|c|c|c|c|c|c|}
\hline 1 & 2 & 3 & 4 & 5 & 6 \\
\hline 3 & $\begin{array}{c}\text { Emotional } \\
\text { tension }\end{array}$ & $\begin{array}{l}\text { Depression of } \\
\text { alpha-rhythm, } \\
\text { increased delta- } \\
\text { rhythm, the } \\
\text { appearance of } \\
\text { significant } \\
\text { fluctuations }\end{array}$ & $\begin{array}{l}\text { Significant increase in } \\
\text { heart rate with } \\
\text { negative emotions, } \\
\text { increase in systolic } \\
\text { index }\end{array}$ & $\begin{array}{c}\text { Constant } \\
\text { fluctuations in the } \\
\text { potential of } \\
\text { considerable value, } \\
\text { the response to a } \\
\text { positive signal } \\
\text { hidden }\end{array}$ & $\begin{array}{l}\text { Characteristic } \\
\text { change of } \\
\text { diction, } \\
\text { significant } \\
\text { change of breath }\end{array}$ \\
\hline 4 & $\begin{array}{l}\text { The state of } \\
\text { fatigue }\end{array}$ & $\begin{array}{l}\text { Decrease of } \\
\text { evoked potentials } \\
\text { number, the } \\
\text { appearance of } \\
\text { delta- rhythm, a } \\
\text { decrease of alpha- } \\
\text { rhythm activity }\end{array}$ & $\begin{array}{l}\text { Significant increase in } \\
\text { heart rate, arrhythmia, } \\
\text { decreased potential of } \\
\text { T-wave peak }\end{array}$ & $\begin{array}{l}\text { A weak response to } \\
\text { positive signals, a } \\
\text { constant oscillation } \\
\text { potential, and } \\
\text { paradoxical } \\
\text { responses }\end{array}$ & $\begin{array}{c}\text { Decreased } \\
\text { attention span, } \\
\text { faster breathing }\end{array}$ \\
\hline 5 & $\begin{array}{l}\text { State of } \\
\text { insufficient } \\
\text { information }\end{array}$ & $\begin{array}{l}\text { The appearance of } \\
\text { beta - rhythm }\end{array}$ & $\begin{array}{c}\text { Against the } \\
\text { background of low } \\
\text { and equal heart rate, } \\
\text { sharp changes are } \\
\text { observed }\end{array}$ & $\begin{array}{l}\text { Spontaneous } \\
\text { fluctuations of the } \\
\text { potential, the } \\
\text { general low } \\
\text { activity of the } \\
\text { reaction } \\
\end{array}$ & $\begin{array}{c}\text { Slowing of } \\
\text { speech, apathy }\end{array}$ \\
\hline 6 & $\begin{array}{c}\text { Information } \\
\text { overload state }\end{array}$ & $\begin{array}{l}\text { The presence of } \\
\text { beta-rhythm, a } \\
\text { large number of } \\
\text { evoked potentials }\end{array}$ & $\begin{array}{l}\text { Significant increase in } \\
\text { heart rate during } \\
\text { prolonged load, } \\
\text { increase in systolic } \\
\text { index }\end{array}$ & $\begin{array}{c}\text { Constant } \\
\text { significant changes } \\
\text { in potential }\end{array}$ & $\begin{array}{l}\text { Significant fast } \\
\text { breathing, errors } \\
\text { in oral arithmetic }\end{array}$ \\
\hline
\end{tabular}

In psychophysiological research, the ECG is most often used as an indicator of the general condition of the human body or its reaction to any external influence. This is the most studied method of measuring and analyzing of a functional state. This method is widely used in clinical practice as a tool for studying the cardiovascular system. Also, in psychophysiology, the ECG serves the main indicator of a person's emotional state during physical and mental stress [11, 13].

The primary characteristics of the ECG are heart rate and its variability, changes in peaks and intervals. Any registration of cardiovascular system characteristics depends on the purpose of research. In the heart muscle, some potentials are conducted by the surrounding tissues. Changes in these potentials are recorded by special devices $[11,13,14]$. The curve recorded in this way is called a cardiogram. Registration of ECG is carried out in standard or non-standard leads, depending on the problem to be solved. To record this data in standard leads, the person should lay in a quiet relaxed state.

Registration of an ECG in non-standard leads allows defining the changes of its different elements: pulse rate, systolic indicator, and relative change of intervals. Recorded cardiogram in different leads has a varied appearance, but always quite clearly expressed specific changes in potential - peaks. These peaks (their amplitude, duration, and distance to the next peak) are the main characteristics of the activity and condition of the heart.

ECG analysis is a method of the human's body regulation mechanisms assessment and heart rate variability (HRV) calculation. Also, HRV analysis is often used to determine the SI. This is an indicator used to assess the degree of regulatory mechanisms stress, based on the variation of heart rate. SI characterizes the activity of sympathetic regulation mechanisms and a condition of the nervous system's central contour. It is calculated based on the cardio intervals distribution graph (variation pulsegram), or by the formula [15]: 


$$
S I=\frac{A M o(\%)}{(2 \Delta X \cdot M o)},
$$

where $\mathrm{A} M o(\%)$ - the value of Moda in percent; $\Delta X$ - the variation range; $M o$ - the most common value among R-R intervals;

Normally, the IN varies between $80-150$ c.u. This indicator is extremely sensitive to the increasing of the sympathetic nervous system's tone. A small load increases it by 1.5-2 times, with significant loads it can be increased by $5-10$ times. Often the values of human SI are divided into the phases [15]:

- great monotony - less than 30 c.u.;

- moderate monotony $-30-50$ c.u.;

- mild monotony - 50-100 c.u.;

- functional comfort - 100-160 c. u.;

- the tension of adaptation mechanisms - 160-200 c.u.;

- overstressing adaptation mechanisms - 200-300 c.u.;

- adaptation failure, stress - more than 300 c.u.

\section{RESEARCH OF STRESS INDEX AND PROCESSING OF THE RESULTS}

The first stage of research was experimental measurements of drivers' functional state in the laboratory. This is done to determine the optimal psychophysiological features in a restful state. The ECG of the subject was recorded using a device "Cardio Sens", which is an accessory of small size and five leads, which are fixed on the driver`s body (Fig. 1).
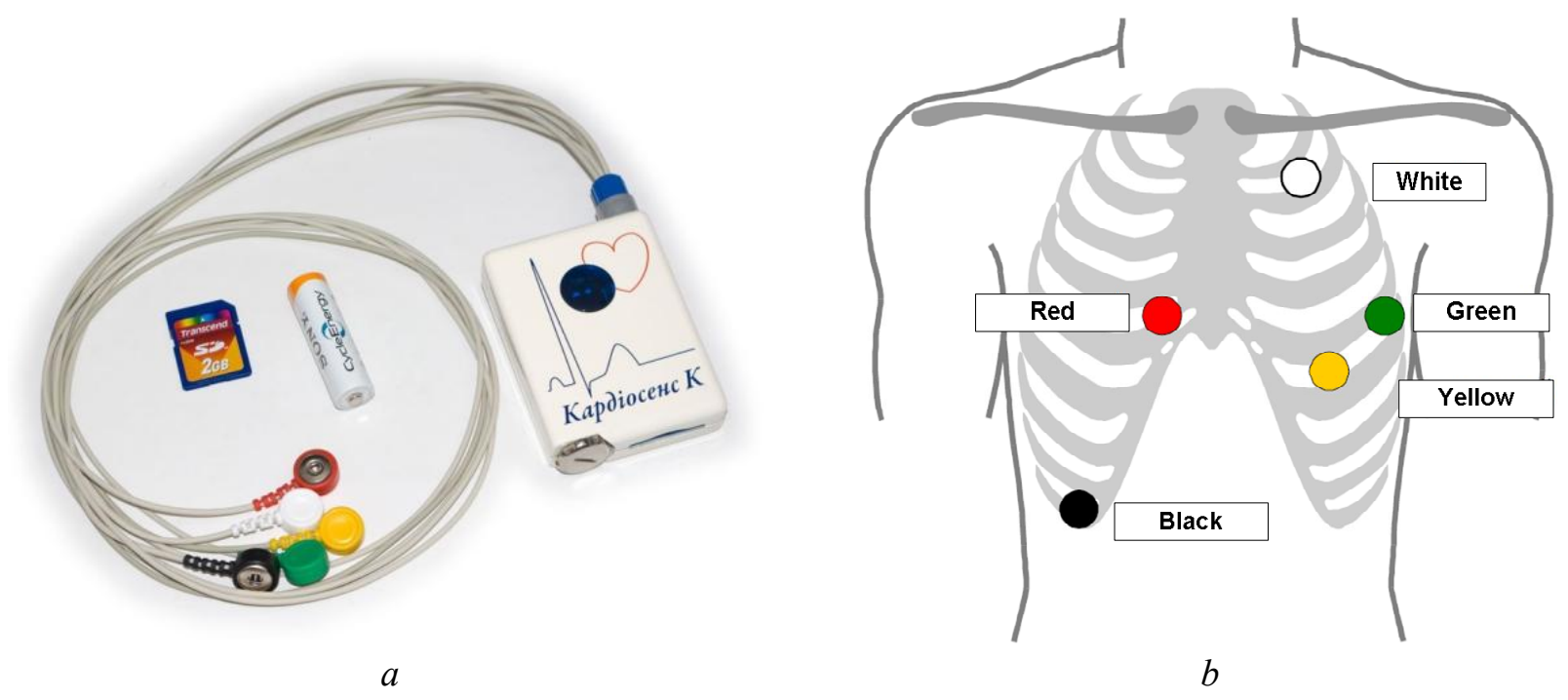

Fig. 1. Cardio Sens ECG recorder (a) and five leads fixed on the person `s body (b) [16]

Also, this tool is quite practical for research in the car, because all the leads are attached to the driver's body and allow him to perform the all necessary actions.

HRV analysis is a method of assessing the state of physiological functions regulations in the human body, in particular, the general activity of regulatory mechanisms, neurohumoral regulation of the heart, the interconnection between sympathetic and parasympathetic divisions of the autonomic nervous system. The SI indicator was used for HRV analysis. The analysis of the cardiogram was performed in the software environment "Cardio Sens" (Fig. 2) [16].

The driver can not be physically immobile during the movement, so the program determines the time intervals in the cardiogram that are not inherent for the human body. These intervals are called "incomprehensible artifacts". It can appear because of the movements that the driver makes while driving (shifting gears, etc.). These "artifacts" do not carry an information load, so they can be neglected, and they 
should be removed from the record. After the analysis of the cardiogram, the "Cardio Sens" environment creates a report in which the scientist can find several medical indicators regarding the state of the cardiovascular system of the person (Fig. 3).

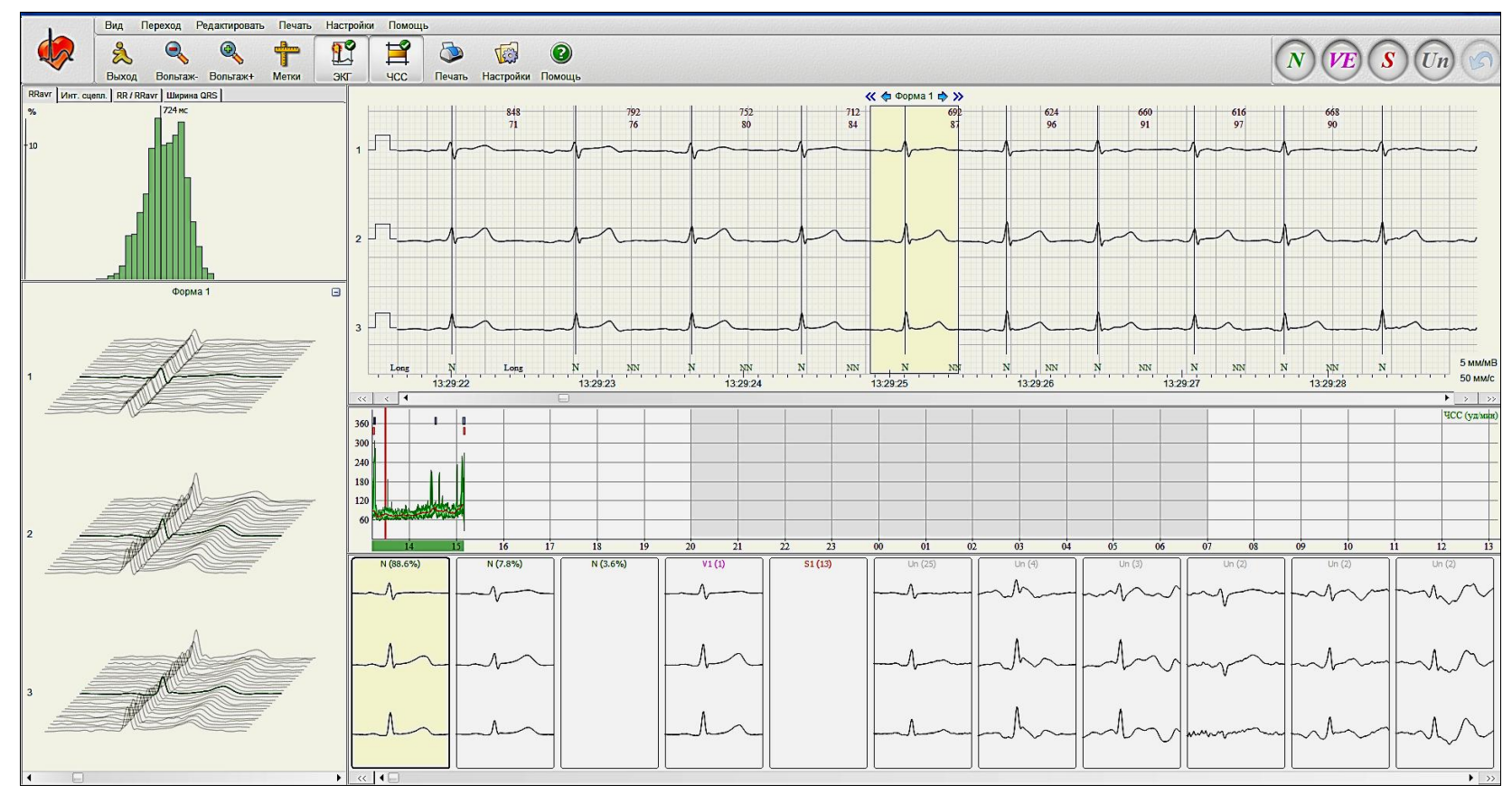

Fig. 2. The process of the driver's ECG fragment analysis in the software environment "Cardio Sens"

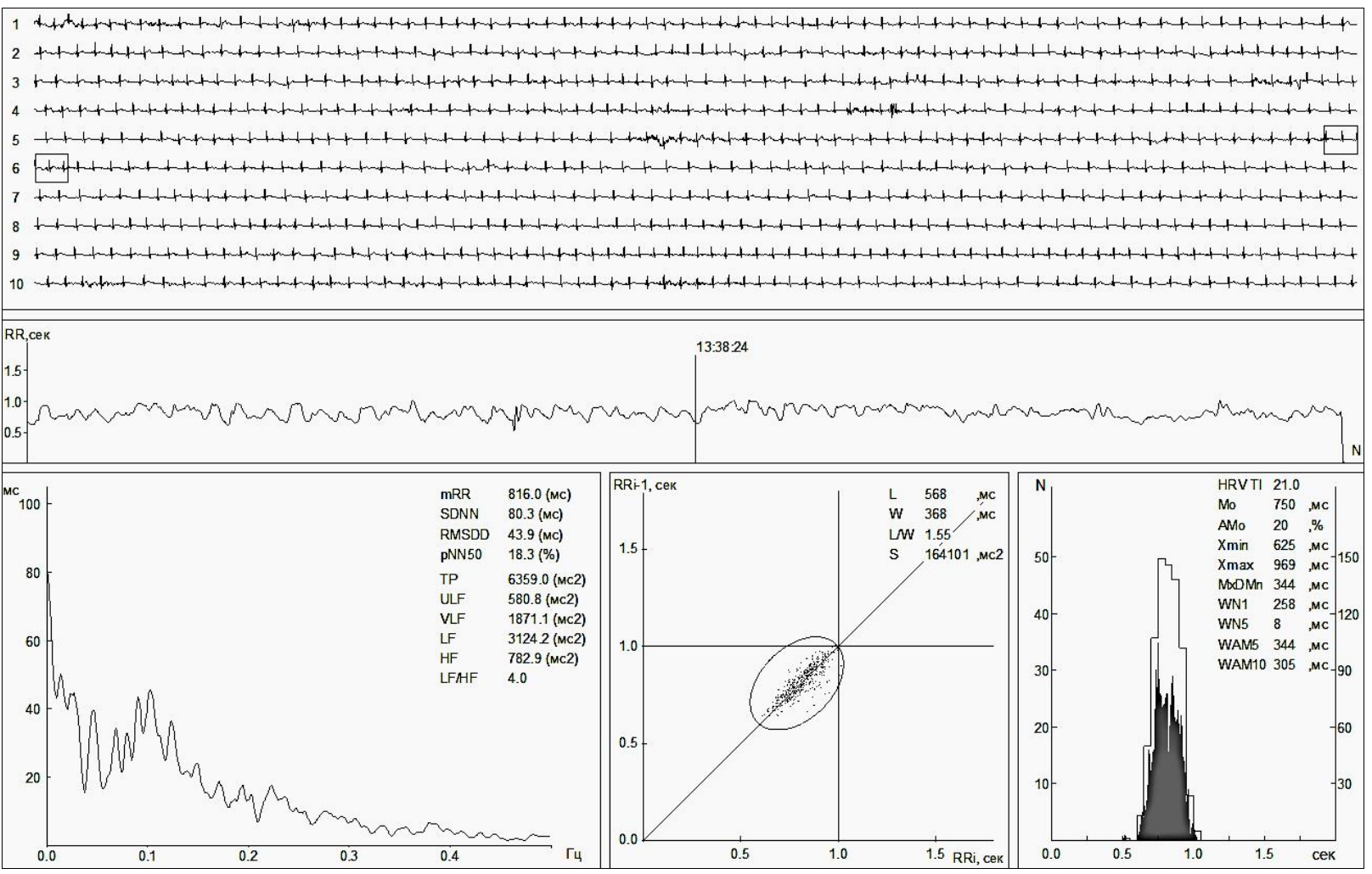

Fig. 3. Fragment of "Cardio Sens" report

The method of driver's functional state research in various movement conditions is special by that all experiments need to be carried out while the car is in motion. That is why the research should be 
performed by a group of people and at different time intervals. In addition to recording the driver's ECG, various events that occur while driving should also be noted. It is also important to keep track of the time while driving and mark the distances traveled by car. The collected data are used for a detailed analysis of the research.

The studies were conducted after the driver`s rest (for 2 days), during peak periods of the day. So the traffic conditions were as close as possible to the conditions under which drivers usually move. These periods are chosen to determine the body's performance. As for the parameters of traffic routes, the streets on which the driver has moved had the following criteria:

- streets must be of the same type according to their planning parameters;

- traffic flow indicators on the streets should be similar in the relevant periods of the day;

- similar parameters of environment (pedestrian crossings, traffic lights, parking lots, the presence of pedestrian flows, etc.).

The research was conducted in real road conditions with the use of a car - Fiat Doblo. It was additionally equipped with a video recorder and items that recorded the speed and geodata on the position of the car. There were no special training places for the experiments. All researches were carried out on the road network involving a group of drivers. Their temperament was also taken into account. Thus, this group had the following percentage of drivers with different temperament types:

- choleric $-28 \%$;

- sanguines $-30 \%$;

- phlegmatics $-25 \%$;

- melancholics $-17 \%$.

This group was formed taking into account the fact that usually in real conditions there are drivers with just such a temperament in approximately the same ratio in the traffic flow.

The driver's ECG was analyzed at five-minute intervals. Based on this, the value of the mode, its amplitude, and the variational range of R-R intervals were obtained. The value of the driver's SI was calculated according to formula (1). For example, some results of one driver's SI at different times of the day are shown in Table 2.

Table 2

Results fragment of one driver's SI at different times of the day

\begin{tabular}{|c|c|c|c|c|c|c|}
\hline \multirow{3}{*}{$\begin{array}{l}\text { Measurement } \\
\text { number }\end{array}$} & \multicolumn{6}{|c|}{ Driver`s SI at different times of the day, c.u. } \\
\hline & \multicolumn{2}{|c|}{ Morning period } & \multicolumn{2}{|c|}{ Middle period } & \multicolumn{2}{|c|}{ Evening period } \\
\hline & Period & The value of SI & Period & The value of SI & Period & The value of SI \\
\hline 1 & $8: 50$ & 86 & $13: 25$ & 134 & $18: 35$ & 199 \\
\hline 2 & $8: 55$ & 105 & $13: 30$ & 133 & $18: 40$ & 147 \\
\hline 3 & 9:00 & 128 & $13: 35$ & 180 & $18: 45$ & 126 \\
\hline 4 & $9: 05$ & 169 & $13: 40$ & 177 & $18: 50$ & 157 \\
\hline 5 & $9: 10$ & 153 & $13: 45$ & 238 & $18: 55$ & 167 \\
\hline 6 & $9: 15$ & 134 & $13: 50$ & 217 & $19: 00$ & 174 \\
\hline 7 & $9: 20$ & 174 & $13: 55$ & 194 & $19: 05$ & 171 \\
\hline 8 & $9: 20$ & 174 & $13: 55$ & 194 & 19:05 & 171 \\
\hline 9 & $9: 25$ & 169 & $14: 00$ & 184 & $19: 10$ & 156 \\
\hline 10 & $9: 30$ & 174 & $14: 05$ & 250 & $19: 15$ & 155 \\
\hline 11 & $9: 35$ & 154 & $14: 10$ & 245 & $19: 20$ & 128 \\
\hline 12 & $9: 40$ & 141 & $14: 15$ & 191 & $19: 25$ & 147 \\
\hline 13 & $9: 45$ & 130 & $14: 20$ & 199 & $19: 30$ & 152 \\
\hline 14 & $9: 50$ & 108 & $14: 25$ & 183 & $19: 35$ & 152 \\
\hline
\end{tabular}

To compare the drivers' functional state, a graph of changes in their SI during the studied periods of the day was created (Fig. 4). Also, for a visual representation of the changes, the indicators obtained in the laboratory conditions (calm state) are shown on the graph. 


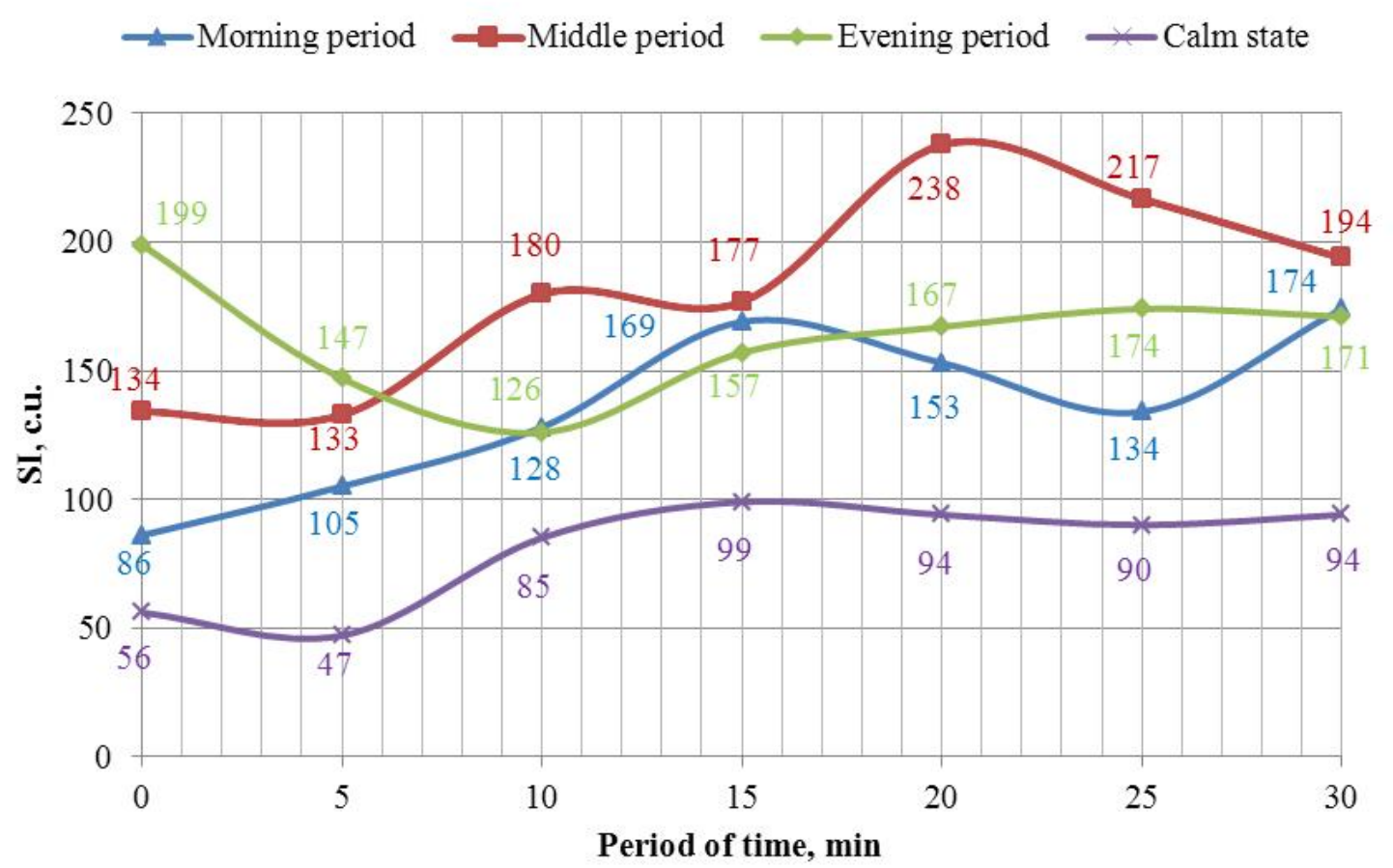

Fig. 4. Changes of drivers 'SI during the studied periods of the day

As it is shown in Fig. 4, the SI of drivers at a restful state is at a lower level than during their work. This is because in such conditions their body does not require additional energy to:

- distribution and concentration of attention on the objects of the external environment;

- performance of certain physical actions related to driving a car;

- perception of external influencing factors;

- processing a significant amount of information, etc.

It should be noted that the value of the driver's SI at a restful state did not exceed 100 c.u, so it was within the norm and mild monotony. As for the periods of driving, the driver's SI reached much higher values. So, for example, in the morning the values of this indicator fluctuated from 78-109 c.u. at the beginning of work to $162-215 \mathrm{c}$.u. at the end of the research period (30 min.). The deterioration of drivers' functional state during this period can be explained by the fact that drivers entered the period of work, and their body began to adapt to the factors of environmental influences. The highest values of driver's SI were observed at the "middle period". This is because during this period the lower values of traffic intensity were observed on the streets where the study was conducted. According to this value, the street's roadcapacity ratio became smaller, and the driving conditions were optimal. Due to that, there were higher speeds, which led drivers to pay more attention to driving. As a result, such movement conditions had a greater impact on their body.

After conducting a mathematical analysis of the obtained data, it was found that the change in the studied drivers ' functional state was most accurately reflected by the second-degree polynomial function. Respectively, the following mathematical dependences on the change of SI on the duration of work ( $t)$ were established:

- morning period:

$$
S I=-0.11 \cdot t^{2}+5.61 \cdot t+85.36
$$

- middle period:

$$
S I=-0.15 \cdot t^{2}+7.51 \cdot t+119.19
$$

- evening period:

$$
S I=0.16 \cdot t^{2}-4.82 \cdot t+182.24
$$


The coefficient of determination for the established mathematical dependences was:

- $\quad$ morning period $-R^{2}=0.77$;

- middle period $-R^{2}=0.78$;

- evening period $-R^{2}=0.56$.

The low value of the determination coefficient in the "evening period" can be explained by the fact that during this period the drivers of private cars have fatigue from their main work. Also, a significant variation in their SI values is a consequence of different workloads during the day. Respectively, there is a need in taking into account the initial drivers` functional state before starting their trips. This is because with the unsatisfactory values of driver's SI, the probability of their erroneous actions while driving a vehicle increases. This can lead to an accident.

\section{CONCLUSIONS}

1. Drivers of private cars were involved in the research. They traveled on the routes "job - home" and "home - job" and for labor purposes. At the same time, only those ECG recordings were taken into account when the drivers were in the same road conditions. Therefore, photo and video recording devices were used for this purpose.

2. With the help of the technical devices and software "Cardio Sens", the ECG of drivers was registered while driving. In the laboratory, the analysis of the obtained data was performed and the necessary HRV indicators for calculating the values of drivers' SI were established. The analysis was performed at five-minute intervals with pre-filtering of the ECG recording.

3. The obtained HRV values were processed in the Microsoft Excel software environment and SI was calculated. It ranged from 41 c.u. (calm condition) up to 250 c.u (middle period). According to this, the dynamics of changes in the SI of the studied drivers during different periods of the day were established. Based on this, a graphical and mathematical dependence on the change of this indicator was created. Thus, there is a need for a detailed analysis of drivers' functional state before the start of their trips as it can act as an indicator of their readiness regarding the driving of the vehicle.

\section{References}

1. Stepanov O. V. (2015). Vplyv psykholohichnoho chynnyka liudyny na bezpeku systemy "Vodii - Avtomobil Doroha - Seredovyshche" [Impact of psychological human factor on safety of the Driver - Automobile - Road Environment system]. Teoriia i praktyka upravlinnia sotsialnymy systemamy [The theory and practice of social systems management], Volume 4, 85-93. (in Ukrainian).

2. Braun, M., \& Serres, K. (2017, September). Asam: an emotion sampling method for the automotive industry. Proceedings of the 9th International Conference on Automotive User Interfaces and Interactive Vehicular Applications Adjunct, 230-232. (in English).

3. Thomas M. Gable, Andrew L. Kun, Bruce N. Walker, \& Riley J. Winton (2015). Comparing heart rate and pupil size as objective measures of workload in the driving context: initial look. Proceedings of the 7th International Conference on Automotive User Interfaces and Interactive Vehicular Applications (AutomotiveUI '15). Association for Computing Machinery, New York, NY, USA. 20-25. doi: 10.1145/2809730.2809745 (in English).

4. Hill, J. D., \& Boyle, L. N. (2007). Driver stress as influenced by driving maneuvers and roadway conditions. Transportation Research Part F: Traffic Psychology and Behaviour, 10(3), 177-186 (in English).

5. Bock, F., Siegl, S., Bazan, P., Buchholz, P., \& German, R. (2018). Reliability and test effort analysis of multi-sensor driver assistance systems. Journal of Systems Architecture, 85, 1-13. doi: 10.1016/j.sysarc.2018.01.006 (in English).

6. Hiuliev N. U. (2016). Liudskyi faktor i dorozhni zatory [Human factor and traffic congestion]. Kharkiv: O.M. Beketov NUUE (in Ukrainian).

7. Wilson, G. F., \& Russell, C. A. (2003). Operator functional state classification using multiple psychophysiological features in an air traffic control task. Human Factors, 45(3), 381-389. doi : 10.1518/hfes.45.3.381.27252 (in English)

8. Kuznetsov, A., Mutaeva, I., \& Kuznetsova, Z. (2017). Diagnostics of functional state and reserve capacity of young athletes' organism. In icSPORTS, 111-114. doi: 10.5220/0006513901110114 (in English). 
9. Prasolenko, O., Burko, D., \& Halkin, A. (2017). Galvanic skin response as a estimation method of the driver's emotional state. American Journal of Science, Engineering and Technology, 2(1), 50-56. (in English).

10. Prasolenko, O., Lobashov, O., \& Galkin, A. (2015). The human factor in road traffic city. International Journal of Automation, Control and Intelligent Systems, 1(3), 77-84. (in English).

11. Postranskyy T. M. (2015). Metodyka doslidzhennia funktsionalnoho stanu vodiiv transportnykh zasobiv [Methods of the vehicle driver's functional state investigation]. Naukovo-vyrobnychyi zhurnal «Avtoshliakhovyk Ukrainy» [Scientific and Industrial Journal "The Avtoshliakhovyk Ukrayiny"], Volume 3, 30-34. (in Ukrainian).

12. Wang F. (2014). Comprehensive Analysis of Fatigue Driving Based on EEG and EOG. Journal of Northeastern University, 175-178 (in English).

13. Singh, R. K., Sarkar, A., \& Anoop, C. S. (2016, May). A health monitoring system using multiple non-contact ECG sensors for automotive drivers. IEEE International Instrumentation and Measurement Technology Conference Proceedings, 1-6. doi: 10.1109/I2MTC.2016.7520539 (in English).

14. Zontone, P., Affanni, A., Bernardini, R., Piras, A., \& Rinaldo, R. (2019, September). Stress detection through electrodermal activity (EDA) and electrocardiogram (ECG) analysis in car drivers. 27th European Signal Processing Conference (EUSIPCO), 1-5. doi : 10.23919/EUSIPCO.2019.8902631 (in English).

15. Prykhodko V., \& Chernykh V. (2019). Vyznachennia rivnia uvahy ta indeksu napruzhennia vodiia v laboratornykh umovakh $\mathrm{v}$ rizni periody doby [Determining the attention level by the functional indicator of the stress index in different periods of day]. Problemy z transportnymy potokamy i napriamy yikh rozviazannia. III vseukrainska naukovo-teoretychna konferentsia [Problems with traffic flows and directions of their connection. III Ukrainian scientific-theoretical conference], 134-136. (in Ukrainian).

16. Medychne obladnannya [Medical equipment]. Retrieved from https://xai-medica.com/ua/equipments.html (in Ukrainian).

Received 25.06.2020; Accepted in revised form 15.09.2020. 